\title{
"Just as fragments are part of a vessel": a translation into medieval Occitan of the life of Alexander the Great
}

Article

Published Version

Leglu, C. (2014) "Just as fragments are part of a vessel": a translation into medieval Occitan of the life of Alexander the Great. Florilegium: Journal of the Canadian Society of Medievalists/Société canadienne des médiévistes, 31. pp. 5576. ISSN 2369-7180 doi: https://doi.org/10.3138/flor.31.03 Available at https://centaur.reading.ac.uk/37987/

It is advisable to refer to the publisher's version if you intend to cite from the work. See Guidance on citing.

Published version at: http://www.utpjournals.press//oi/flor

To link to this article DOI: http://dx.doi.org/10.3138/flor.31.03

Publisher: Wilfrid Laurier University Press

All outputs in CentAUR are protected by Intellectual Property Rights law, including copyright law. Copyright and IPR is retained by the creators or other copyright holders. Terms and conditions for use of this material are defined in the End User Agreement.

www.reading.ac.uk/centaur 
Central Archive at the University of Reading

Reading's research outputs online 


\section{"Just as Fragments are Part of a Vessel": A Translation into Medieval Occitan of the Life of Alexander the Great*}

\section{Catherine Léglu}

This article examines the Occitan prose life of Alexander the Great in the Abreujamen de las estorias, a translation of fragments of a late antique Latin life of Alexander that was not usually put into the vernacular. ${ }^{1}$ Those who selected and translated part of Justin's Epitome of the Historiae Philippicae of Pompeius Trogus had little knowledge of pagan Latin materials and used non-literary forms of Occitan. Their work involved more than just linguistic transposition; they omitted fantastical lore as well as pagan religious practices. It is in effect a work of what John Milton has called "trans-creation," especially in their imaginative selection of other sources concerning Alexander to either fill gaps or to resolve problems that they were encountering in Justin. ${ }^{2}$

Medieval lives of Alexander the Great are an invaluable source of knowledge about the ways in which classical and medieval texts were apprehended, appropriated, rejected, and reassembled. The texts are invariably translations of

* A shorter version of this paper was presented at the conference "Medieval Translation, Afterlives and Decay," organized by Luke Sunderland and Thomas Hinton, at Durham University, June 2013; the paper emerges from a research project funded by a grant provided by the Leverhulme Trust. I thank my two research fellows, Federico Botana and Alexander Ibarz, for their support. For further comments and suggestions I also thank Gianfelice Peron, Francesca Gambino, Michele Campopiano, Roberta Morosini, Paolo Rinoldi, and other participants at the conference "Alessandro Magno nel Veneto medievale e dintorni," Padua, 25-26 May 2015.

1 See Botana, "The Making of L'Abreujamen"; Ibarz, "The Provenance of the Abreujamens"; and Léglu, "A Genealogy."

2 Milton, "Between the Cat and the Devil," 53, 57. 
translations: their earliest source, the original Life written in Greek by PseudoCallisthenes, has been lost for centuries. The Alexander the Great tradition is polyphonic and can be studied across a wide range of versions. ${ }^{3}$ Its development in the later Middle Ages, when classical works were rendered in the vernacular with a new concern for adhering to the source, is especially interesting. ${ }^{4}$ Editors and critics can be optimistic about encountering an example of Walter Benjamin's famous vision of translation as archaeological reconstruction:

a translation, instead of resembling the meaning of the original, must lovingly and in detail incorporate the original's mode of signification, thus making both the original and the translation recognizable as fragments of a greater language, just as fragments are part of a vessel..$^{5}$

The Alexander tradition, multilingual and multifaceted as it is, can be thus conceived of as the many fragments of a single vessel. Language plays an important but sometimes overlooked part in this work of reconstruction. Many versions mean many interpretations and reinterpretations of the language of the source (although the Greek of Pseudo-Callisthenes is lost).

Medieval translations and adaptations can be problematic for anyone who wishes to apply Benjamin's ideal of translating with an eye to preserving the text's original integrity, in order to allow the original text to be both known and respected on its own terms:

A real translation is transparent; it does not cover the original, does not block its light, but allows the pure language, as though reinforced by its own medium, to shine upon the original all the more fully. ${ }^{6}$

Benjamin proposes that the translator should strive to allow the new text to work in a clear and open dialogue with its source, not in terms of the style but in terms of the sense. Benjamin's redefinition of the task of the translator can be brought into dialogue with a recent attempt by Gary Bortolotti and Linda

3 For general studies of this tradition, see Cary, The Medieval Alexander; Gosman, La légende d'Alexandre; Gaullier-Bougassas, Les Romans d'Alexandre. See also Léglu, "The Child of Babylon."

4 For Latin-vernacular exchange in this period, see Lusignan, Parler vulgairement; Kelly, "The Fidus interpres"; Long, "Medieval Literature." Related issues are explored in Léglu, "Translating Lucretia."

5 Benjamin, "The Task of the Translator," 78. See also the discussion by Gilbert, "The Task of the Dérimeur."

6 Benjamin, "The Task of the Translator," 79.

DOI: $10.3138 /$ flor.31.03

Florilegium 31 (2014) 
Hutcheon to define a relationship between biological adaptation and the creation of multiple new adaptations of a canonical text. Bortolotti and Hutcheon reject the evaluative criterion of fidelity to the source text in favour of a focus on process: "both organisms and stories 'evolve' - that is, replicate and change." Thus, the degree to which a given work replicates its 'ancestor' with any exactitude (in the sense that this textual source can be understood as providing a blueprint for its 'descendants') is not of primary importance; rather, in this context, it is essential to think in terms of the diversity and energy inherent in lineages of descent,' and to value, precisely, both that energy and that diversity when analysing versions that carry what might be termed mutations. No matter whether it is regarded as a filter for a fixed original or as one of the innovative, diverse descendants of that original, the Occitan text offers glimpses of transformative processes of selection and omission. There are some risks involved in ascribing intentionality to such processes, as they are often determined by numerous factors, not least the quality of the sources available.

The Abreujamen de las estorias is the main part of a compilation of translations into Occitan that now survives in two manuscripts (hereafter $\mathrm{L}^{1}$ and $\mathrm{L}^{2}$; see Table 1). It is an illustrated, diagrammatic world history from Creation to the early 1320s. Its Latin equivalent is the Franciscan friar Paolino Veneto's Compendium gestarum rerum regnorumque originem, c.1321-1326 (hereafter M). ${ }^{8}$ Paolino Veneto was involved personally in the creation of the Occitan Abreujamen de las estorias between 1321 and 1324, probably while in the entourage of Pope John XXII, where he served as an apostolic penitentiary. Both $\mathrm{M}$ and $\mathrm{L}^{1}$ were illustrated in Avignon. While the Abreujamen itself can be attributed to Paolino as its instigator, both it and its companion translations were produced by several contributors. ${ }^{9}$ Paolino's close connection with his fellow Venetian and crusading propagandist Marino Sanudo il Vecchio dates from this time (he was part of a papal commission that examined his book, the Liber secretorum fidelium crucis, in the spring of 1321), but the Abreujamen does not share the anti-Islamic

7 Bortolotti and Hutcheon, "On the Origin of Adaptations," 446.

8 For general studies of Paolino Veneto and his works, see Ghinato, Fr. Paolino da Venezia; Degenhart and Schmitt, "Marino Sanudo und Paolino Veneto"; Heullant-Donat, "Entrer dans l'histoire." See also Heullant-Donat's unpublished doctoral dissertation "Ab Origine Mundi."

9 Botana, "The Making of L'Abreujamen," and Ibarz, "The Provenance of the Abreujamens." 
content of Paolino's works in Latin. ${ }^{10}$ The contents of the vernacular and Latin codices were structured differently:

\section{British Library, Egerton MS $1500\left(\mathrm{~L}^{1}\right)$}

Item 1:

L'Abreujamen de las estorias

Includes a genealogy of the pagan

gods, the Historia Alexandri, and a history of the crusades

British Library, Add. MS 17920

$\left(\mathrm{L}^{2}\right.$, originally part of $\mathrm{L}^{1}$ )

Item 1:

Dels miracles de Sainhta Maria Vergena (Marian miracles)

Item 2:

"The Marriage of the Seven Daughters of the Devil"

Item 3:

Pseudo-Turpin Chronicle Cl1 $^{11}$

Item 4:

The Marvels of Ireland ${ }^{12}$

\section{British Library, MS Egerton}

\section{$1500\left(\mathrm{~L}^{1}\right)$}

fols. 61-65:
Venice, Bibl. Marciana, cod. Z latino 399 (=1610) (M)

Item 1:

Paolino Veneto, Compendium gestarum rerum regnorumque originem

Item 2:

Provinciale romanum

The manuscript includes sketches and drafts of parts of Paolino's later work, the Satyrica Historia (c.13351339).

Provinciale romanum in Occitan

Table 1. The manuscript context of the Abreujamen de las estorias.

The Abreujamen is a chronology of the world, but it also contains a handful of independent treatises, including a short prose life of Alexander the Great entitled the Historia Alexandri - La istoria dalixandre. The Historia takes up two facing folios, in addition to part of the preceding recto and the following

10 On Paolino's anti-Islamic texts, see Morosini, "Boccaccio 'secundum venetum'."

11 Léglu, "The Devil's Daughters"; Ricketts, "Deux textes en occitan médiéval”; Piccat, ed., La versione occitana dello Pseudo Turpino.

12 Ricketts and Hershon, "Las Merevilhas de la terra de Ybernia." 
verso ( $\mathrm{L}^{1}$, fols. $\left.13 \mathrm{r}-14 \mathrm{v}\right)$. Its relationship with the Latin text of $\mathrm{M}$ does not follow the usual model of Latin source / vernacular translation. In M, the life of Alexander the Great is embedded within a series of notes concerning conflict between Persia and Macedon and concerning the reigns of Syria, Egypt, and Persia (M, fols. 15r-16v). It is similar to the Historia Alexandri but longer and more diffuse and is evidently based on shared sources, but it is not identical to it. For clarity's sake, this article discusses only the text that appears in the Abreujamen.

The earliest surviving fragment of the Old French Roman d'Alexandre, written in a southern French dialect, is copied into the margin of a ninth-century manuscript of Quintus Curtius. It places the vernacular verse tradition in the margins of a Latin prose work that was not translated into French until the fifteenth century. ${ }^{13}$ As Humanism emerged in papal Avignon and in various regions of fourteenth-century Italy, the works of the pagan classical authors were caught in a complicated process of translation, non-translation, and exegesis, marked by deference to the letter of the text. ${ }^{14}$ Latin auctores were also valued increasingly for the intrinsic linguistic and historical interest of their works. As will be shown below, the version of the life of Alexander the Great that appears in the Abreujamen de las estorias is both attentive to the letter of its classical Latin source and departs from it by inserting fragments of the medieval Alexander tradition. It is simultaneously transparent, in the sense that it allows the alert reader to detect the Latin text that it renders, and opaque as a result of the translators' process of omission and selection. It confects a vessel from multiple fragments, but it makes little effort either to indicate its multiple and conflicting sources or to smooth over the cracks. It does, however, betray an ideological agenda in that it downplays the pagan aspects of the legend.

As Lynne Long suggests, "It is easy to assume or assign a motive retrospectively for the act of translation to suit the commentator's own historical perspective, whereas in fact the translator's primary motive for translating and the strategies employed often confronted a quite different and more complex reality." 15 The following sections therefore devote some attention both to traces of an intended reader and to the hypothesis that Paolino and his colleagues worked from a copy of Justin's work rather than from a digest.

\footnotetext{
13 See MFRA 3:2-8, 37-60. Bossuat, "Vasque de Lucene."

14 Griffin, "Translation and Transformation."

15 Long, "Medieval Literature," 63.
} 


\section{The Choice of Justin's Epitome of Pompeius Trogus}

In any study of translation, the source is the key. This Historia Alexandri is chiefly an abbreviated version of Justin's abbreviation of Pompeius Trogus's Philippic History (Orosius called Justin the breviator of Trogus). ${ }^{16}$ Justin's Epitome, produced c. 200 C.E. from a text dating from the first century B.C.E., was widely read in the Middle Ages as a universal history. According to AlonsoNúñez, it was also "the only world history written in Latin by a pagan." ${ }^{7}$ Diodorus Siculus and Nicolaus of Damascus had written their world histories in Greek, and, in the early fifth century, Orosius composed a Christian world history in Latin, as Eusebius had done a century earlier. Trogus also innovated in his concern for the Parthian Empire, descended from the Scythians, as a valid rival to the Roman Empire (Books XLI-XLII). Following Trogus, Justin provides a detailed history of the kingdom of Macedon and of the successor kingdoms to Alexander's empire, specifically in terms of the reigns of Antiochus and his descendants. Again according to Alonso-Núñez, Justin was distinctive in applying a synchronic approach to historical events based on translatio imperii (from Assyria to Media and Persia, and thence to Macedon and ultimately to Rome), an approach that was adopted by Eusebius-Jerome, albeit with a cruder grasp of both geography and chronology. ${ }^{18}$ However, despite its importance for the medieval understanding of the history of the lands that lay beyond Europe, Justin's Epitome is usually a minor source for lives of Alexander the Great, being overshadowed both by the legendary tradition and by Orosius. ${ }^{19}$ In the early twelfth century, the so-called J2 redaction of the Historia de preliis (J1) was produced with substantial borrowings from Orosius. This text may have been the work of Guido da Pisa, and it certainly proved popular in the Italian peninsula. ${ }^{20}$

16 All quotations from the Latin text are taken from the online edition by Arnaud-Lindet, ed. and trans., Justin, Abrégé des 'Histoires Philippiques' de Trogue Pompée, available at <http:// www.forumromanum.org/literature/justin/index.html>, 2003 and Biblioteca Augustana, 2004. For the meaning of the term epitome, see Justin, Epitome of the Philippic History of Pompeius Trogus, vol. 1, Books 11-12: Alexander the Great, trans. Yardley, commentary by Heckel, 15-19.

17 Alonso-Núñez, "An Augustan World History," 57. Syme, "The Date of Justin."

18 Alonso-Núñez, "An Augustan World History," 62-63.

19 Cary, The Medieval Alexander, 17.

20 Campopiano, "Parcours de la légende d'Alexandre en Italie," 68-71. 
Over two hundred manuscripts of Justin's text survive. Several copies were made in Verona in the late thirteenth century, coinciding with Paolino's education and early career in the Veneto and the Marca Trevigiana. ${ }^{21}$ Paolino drew on Justin for the origins and descent of the Scythians, among them the Amazons (Books I and II). Given the evidence that full copies of Justin's Epitome were available, it must be assumed that both Paolino and the translators worked directly from a Latin source and that they preferred to turn to Peter Comestor rather than to the 'legendary' tradition for supplementary episodes. It is helpful in this respect to note that the papal library at Avignon, which was assembled during the reign of John XXII, held a copy of Justin's work (now Cambridge, Fitzwilliam Museum, MS 264). ${ }^{22}$ Another very important manuscript, Biblioteca apostolica vaticana, MS Vat. Lat. 1860, includes a copy of Justin's Epitome - the only one to provide his full name and to give his work the title Epitome which is part of a compilation of Roman histories of the first half of the fourteenth century (one text is internally dated to 1313). This manuscript is based in part on an exemplar that was at Montecassino, and it is also associated with both the court of Naples and the Franciscan order (thus bringing it close to Paolino's milieu). ${ }^{23}$ While the use of an epitome of Justin's Epitome should not be discounted, it seems more likely that the quotations which survive in $\mathrm{M}$ and $\mathrm{L}^{1}$ are taken directly from a full copy. ${ }^{24}$

A vernacular work such as the Abreujamen must be placed in relation to the best-known medieval Latin source, the Historia de preliis. ${ }^{25}$ A cleric would have been familiar from his schooling with Walter of Châtillon's epic poem, the Alexandreis, which had long been used as a textbook by students of the trivium, sometimes with glosses appended that sought to teach biblical history. ${ }^{26}$ In Italy, the popular thirteenth-century poem by Quilichinus of Spoleto (1236),

21 Cary, The Medieval Alexander, 17. Reynolds, "Justinus," 197-99.

22 My thanks to Stella Panayotova and Nicholas Robinson of the Fitzwilliam Museum, Cambridge, for allowing me access to this very damaged manuscript.

23 Reynolds, "Justinus," 199. See the revised dating proposed by Billanovich, Lezioni, 67-75. The importance of this manuscript is stressed by Arnaud-Lindet, ed., Abrégé; see her Class III, at <http://www.forumromanum.org/literature/justin/introduction.html\#4>.

24 Ross, Alexander Historiatus, 76-77.

25 All references to the Historia de preliis are taken from The Romances of Alexander, trans. Kratz.

26 Walter of Châtillon, The Alexandreis. For schoolroom use, see Townsend, ed., An Epitome of Biblical History. 
based on the Historia de preliis J3, was translated into Italian ottava rima by Domenico Scolari (the only surviving manuscript dates from 1355). ${ }^{27}$ As a Venetian from a privileged family, Paolino Veneto may have known the Venice manuscript of the medieval French Roman d'Alexandre, as well as other versions in French. ${ }^{28}$

In addition to Justin, the text of the Abreujamen includes a handful of interpolations that are traceable to the Historia de preliis as well as to Comestor, to Augustine's City of God, and to the first book of Maccabees (the latter also perhaps via Comestor). Vincent of Beauvais' Speculum Historiale also bases its lengthy biography of Alexander on Justin, but it includes many other sources as well; the text grew over successive redactions to make up the whole of the fourth book. George Cary describes Vincent's biography as "an incoherent series of contradictory statements borrowed from conflicting authors, each excerpt preceded by an acknowledgement of its origin." 29 This is not at all the approach adopted in the Abreujamen. It is implausible that Paolino and his assistants used Vincent of Beauvais, as they would have had to whittle their selection down to extracts from Justin and Comestor. ${ }^{30}$ The early thirteenth-century Histoire ancienne jusqu'à César must also be rejected as a source, as it draws heavily on Orosius and Comestor but also inserts material from a number of Old French romans d'antiquité as well as from Geoffrey of Monmouth. So must the French translation of the Speculum Historiale, the Miroir historial by Jean de Vignay (c.1328-1333). ${ }^{31}$ The rubric "Historia Alexandri" is the title of the biography in the Abreujamen (on fol. 14ra), but it is unlikely to echo the use of that title by Vincent of Beauvais, who is referring to the 'Zacher Epitome,' not to Justin. ${ }^{32}$ To sum up, the Abreujamen ignores the bulk of the 'legendary' Alexander material and omits the most popular 'historical' source of its time, Vincent of Beauvais, in favour of much older texts.

27 Cary, Medieval Alexander, 53. Campopiano, "Parcours de la légende d'Alexandre en Italie," 77-78.

28 For the Venice text, see MFRA 1. For Paolino's strong links with Venice's patriarcate, see Ghinato, Fr. Paolino da Venezia, 15-25.

29 Voorbij, "The Speculum Historiale." Cary, The Medieval Alexander, 73-74.

30 Cary, The Medieval Alexander, 25-26.

31 Cary, The Medieval Alexander, 37; Gosman, "The Life of Alexander."

32 Cary, The Medieval Alexander, 25-26, 74. 
Although the text of the Abreujamen is very condensed, individual sentences are direct translations from Justin (many of the corresponding passages from Justin are cited verbatim in M). For example, Alexander explains that "ni ges no auia demandat lo cors de Dari, mas lo regne" (he did not request the body of Darius, but rather his kingdom), a straightforward rendering of Justin's "nec se corpus, sed regnum Darii petisse" (L $\mathrm{L}^{1}$, fol. 14; Justin, XII.3.3). Much of the translation aims to render the core idea of a particular passage in Justin in terms that would have been comprehensible to the reader without losing its syntactical structure:

Adunato deinde exercitu naues onerat, unde conspecta Asia incredibili ardore mentis accensus duodecim aras deorum in belli uota statuit.

Patrimonium omne suum, quod in Macedonia Europaque habebat, amicis diuidit, sibi Asiam sufficere praefatus.

(Justin, XI.5.4-5)

[Having assembled his troops, he put them on board ship, on which (incredibly excited by the sight of Asia) he erected altars to the twelve gods in order to pray for military success. He divided up among his friends every bit of the property that he had in Macedonia and the rest of Europe, saying that Asia would suffice him.]

Quant ac reguardada Azia, lo seu coratge fo escalfatz.

E deuis a sos amics lo patremoni que auia en Europa, dizens que a lhuy auondaua Azia.

(Abreujamen, $\mathrm{L}^{1}$, fol.13v, col. 2; transcription by Ibarz ${ }^{33}$

[When he had looked upon Asia, his desire was ignited, and he divided his European inheritance up among his friends, saying that Asia was enough for him.]

The Occitan coratge ('desire, 'of the heart') is not a literal equivalent of the Latin "ardore mentis," but it is faithful to the key image of Alexander's excitement as he gazes on the lands that he wishes to conquer. Alexander's idolatry is omitted here, as it is throughout the translation. Having established Paolino's choice of a

33 All quotations from L'Abreujamen are taken from the unpublished transcription by Alexander Ibarz. 
late-classical, pagan writer, it is necessary to turn to what he and his associates chose to omit as they compiled the Historia Alexandri.

\section{Omissions and Interpolations}

Given its scrupulous concern for clarity with respect to the classical source, the omissions of content in the Abreujamen are eloquent. Queen Candace appears, but she is not said to have borne a son, and thus the vernacular Vengeance Alexandre tradition is omitted. Also missing are Alexander's proto-scientific flight into the air and his journey under the sea. The most puzzling omission concerns Alexander's encounters with extraordinary human and semi-human peoples. All have been left out, with the exception of his encounter with the Amazons (Justin, Books I and II), who appear elsewhere in the Abreujamen as important figures in the early history of the world. Furthermore, the Historia Alexandri does not include Alexander's disputed paternity, a major theme in the Old French vernacular tradition that was reproduced without demur by Vincent of Beauvais. The Abreujamen ignores the tradition that Alexander the Great was the illegitimate son of the exiled pharaoh Nectanebus, who had disguised himself as the ram-headed god Ammon to seduce Olympias, the wife of Philip of Macedon. Needless to say, the text also omits Alexander's murder of his biological father.

The result is a history of Alexander the Great on a human scale. It strips the king of his superhuman dimension and empties his world of fantastical races and beasts. Justin's account of Alexander is one of the Stoic-influenced condemnations of the king for his idolatry, his greed, and his desire to turn himself into a god. As will be described below, the translation works hard to erase some of these criticisms from the narrative. This raises the further question why it chooses to exploit Justin as its chief source if the text is inimical to its ideological purpose. ${ }^{34}$

The Historia Alexandri sidesteps the issue of Alexander's paternity by starting with his accession to the throne of Macedon after Philip's assassination. He is his father's avenger:

34 Cary, The Medieval Alexander, 80, 99, 110-12, 290-91. 
Phelip fo ausis per lo fort noble jouencel Pauzania el temps del Rey Arges quar no fazia complimen de drechura az aquel que auia prees dampnatge. E lo filh Alixandre succedic lhy, lo qual fe ausire sobre lo tombel del payre aquels que ero estatz cossentens de la sua mort.

E lo filh Alixandre succedic lhy, lo qual fe ausire sobre lo tombel del payre aquels que ero estatz cossentens de la sua mort.

$\left(\mathrm{L}^{1}\right.$, fol. $13 \mathrm{v}$, col. 1$)$

[Philip was murdered by the most noble youth Pausanias in the time of King Arges, because he had not ensured that justice was done on behalf of the one who had been harmed.

His son Alexander succeeded him; he had those men killed on his father's tomb who had agreed to his murder.]

This brief account of the king's death is a condensation of Justin IX.6.1-8. According to Justin, Philip II of Macedon was murdered by Pausanias of Orestis during a wedding feast. Justin's text states that Pausanias was avenging a longfelt injustice, for he had been assaulted by Attalus, one of the king's men, and subsequently been mocked by him in public. Philip had ridiculed his grievance and made Attalus a general. The Abreujamen appears to use only the last sentence of Justin's chapter: "iram in ipsum Philippum uertit ultionemque, quam ab aduersario non poterat, ab iniquo iudice exegit" (Justin, IX.6.8: he turned his rage against Philip in person and inflicted on him as an unjust judge, the revenge that he could not inflict on him as his enemy). Philip's murder thus appears to result from his lack of a king's concern for justice. The next sentence adapts a segment of text that occurs two books later: "Prima illi cura paternarum exequiarum fuit, in quibus ante omnia caedis conscios ad tumulum patris occidi iussit" (Justin, XI.2.1: His first concern was with his father's funeral, where he had all those who had been implicated in his murder put to death at his father's tomb). Alexander's revenge is retained, but the sentence has lost the information that the executions took place at Philip's funeral and that they included the elimination of a rival claimant. The passage thus condenses several independent segments into a simple exemplum: Philip loses his life for his failure to maintain justice in his realm, and his successor's first act is to ensure that justice is done. Justin does not mention Alexander's disputed legitimacy nor does the translation, but it also elides Justin's inclusion of rival claimants to the throne. 
Many lacunae may thus reflect deliberate choices rather than gaps in the source material.

The translation follows the chronological structure of its source (Justin) systematically, and its interpolations are framed by Justin's text. For example, the siege of Tyre is taken from Justin XI.10, rendered as a single statement: "El pres la cyotat Tyre" (he seized the city of Tyre). This is followed by a famous episode from the Historia de preliis, Alexander's visit to Jerusalem and his meeting with the High Priest Jaddus: ${ }^{35}$

E autreget a Sarabala que bastis lo temple el puech Guarizi. E quant anaua cochozamen destrure Jeruzalem e ui lauesque Jadus en las uestimentas auesquals, el dishendet del caual, e dihs que el auia uist ental semblansa nostre senhor en Licia, cyotat de Macedonia, prometen a lhuy lo regne de Azia. E segon que lo prestre lhy mostret el proferc ostias.

$\left(\mathrm{L}^{1}\right.$, fol.14r, col.1)

[He agreed that Sanballat would build a temple on the hill of Gaza. When he was rushing off to destroy Jerusalem, he saw Bishop Jaddus in bishop's clothing. He dismounted and said that he had seen our Lord in such a guise in Lycia, the city of Macedon, when he had promised him the kingdom of Asia. And, with the guidance of the priest, he made offerings.]

The segment of text closes with a sentence that translates Justin XI.11.1 and 11.13:

Inde Rhodum Alexander Aegyptum Ciliciam sine certamine recepit. [...] Reuersus ab Hammone Alexandream condidit et coloniam Macedonum caput esse Aegypti iubet.

(Justin, XI.11.1 \& XI.11.13)
Aprop ayso el receup senes batalha Rodas e Egipte, e Cilicia, e bastic en Egipte Alexandria. ( $\mathrm{L}^{1}$, fol.14r, col.1)

35 Historia de preliis, trans. Kratz, The Romances of Alexander, 15. Josephus, Antiquities, vol. 4, 11.302-47. See Cohen, "Alexander the Great and Jaddus the High Priest." The name "Saraballa' for Sanballat is attested in vernacular texts; see Ross, Illustrated Medieval Alexander Books, 34. Cary, The Medieval Alexander, 127-30. 
[Next, Alexander of Egypt seized Rhodes, Egypt, and Cilicia without a struggle. [...]

Returned from the temple of Ammon, he founded the city of Alexandria and ordered that this Macedonian colony should be the chief city of Egypt.]
[Thereupon he received - without any battles - Rhodes, Egypt, and Cilicia, and he built Alexandria in Egypt.]

The text has neatly omitted Alexander's visit to the Temple of Ammon, where he pretends to enquire after his own birth and into his future in order to erase the shame of his disputed paternity by being proclaimed a demi-god by the priests. This episode is treated by Justin as the moment when Alexander, inflamed by excessive pride, forgets his Greek education and Macedonian values (Justin, XI.11.2-12). Alexander's meeting in Jerusalem with Jaddus and his sacrifice within the Temple were a popular episode in medieval Alexander books because it implied his conversion. ${ }^{36}$ Here, the translation continues to erase both Alexander's paganism and his irregular birth: the Jerusalem episode is inserted in the Historia Alexandri exactly at the point where, in Justin's version of the narrative, Alexander proclaims his own divinity as the son of the Egyptian god Ammon. In the Historia Alexandri, the Jerusalem episode replaces these events.

A similar wish to make Alexander less pagan is indicated by changes in the language used to describe the libations to the ocean which Alexander makes in the hope of returning home safely, after he has used a plant shown to him in a dream to cure his men of the injuries inflicted by poisoned arrows (Justin, XII.10.4). The poisoned arrows and the miraculous cure after the siege of the city of King Ambiger are left out (Justin, XII.10.2). The libamenta in Justin (offerings to the gods) are rendered sacrifici (sacrifices), and the annotator or corrector has also scored out one mention of sacrifice in favour of an interlinear note that explains that a pagan sacrifice would entail killing animals:

36 Cary, The Medieval Alexander, 127-30. 
Expugnata deinde urbe reuersus in nauem Oceano libamenta dedit, prosperum in patriam reditum precatus.

(Justin, XII.10.4)
[Then, after seizing the city, once he was back on his ship, he made libations to Oceanus, praying for a good return to his homeland].
E quant ac batalhada la cyotat del Rey Ambyger, e fo detornatz en la mar, el preguet la mar

$<$ id est fetz sacrifici ha la mar sacrificando animali> quel layshes tornar en son pays eper/so felhy sacrifizis.

$$
\left(\mathrm{L}^{\mathrm{l}}\right. \text {, fol. 14r, col. 2) }
$$

[When he had fought the city of King Ambiger and turned away onto the sea, he prayed to the sea

$<$ i.e., he made a sacrifice to the sea, sacrificing animals $>$

that it might allow him to return to his country and because of this, he made a sacrifice.]

The pattern of omissions and interpolations in this section of the Historia Alexandri adds up to the erasure of Alexander's pagan religion. More broadly, the text betrays a reluctance to include the pre-Christian aspects of Justin's Epitome.

The translators' work of selection seems to orient their text towards an intended reader. Several marginal notes in the manuscript $\left(\mathrm{L}^{1}-\mathrm{L}^{2}\right)$ give advice on further reading to an unnamed reader who is addressed as "vos senher" (your lordship). ${ }^{37}$ Some of the interlinear glosses can be viewed either as attempts to clarify the Occitan to someone who is unable to comprehend fine points of vocabulary, or as attempts to translate the Occitan into Latin. For example, the following passage, taken from the Historia de preliis, elicits the insertion of two interlinear Latin glosses into the Occitan text:

adonc moric Bucefa <id est equus Alexandri> lo caual d'Alixandre. Quar Porre l'ausis. E en la segonda batalha, quant la batalha Reyal era doptoza longuamen, adonc Porre se reuiret als seus que fazio mazan <id est clamorem $>$, e adonc Alixandre trauquet lho.

$$
\left(\mathrm{L}^{1},\right. \text { fol.14r, col. 1) }
$$

37 See Ibarz, "The Provenance of the Abreujamens," 5-6; and Léglu, "A Genealogy," 19-20. 
[Then Bucephalus died <i.e., equus Alexandri>, the horse of Alexander, because Porus killed it. In the second battle, when the combat of the kings lasted for a long time, then Porus turned towards his men who were making a racket <i.e., clamorem>, and then Alexander killed him.]

Were the translators unable to trust the linguistic competence of their intended reader, or was the vernacular meant as a useful springboard for basic Latin instruction? If so, does the very close rendering of individual phrases from Justin point to the use of the Latin text less as a source than as a book that could be consulted later or alongside the text?

Whereas the Historia Alexandri generally avoids references to pagan religion, a few marvels are preserved. The famous scenes of the crossing of the desert into India and of the encounter with the Trees of the Sun and the Moon are retained, described in the rubric as "merauilhas" (marvels). (In M, the corresponding rubric reads de uariis monstris, 'diverse wonders.') ${ }^{38}$ As they cross the desert, Alexander's men are tormented by thirst. In the Historia de preliis, they find a pool with sweet water and set up camp, but at night they are attacked by the beasts that come to drink at the pool: scorpions, "snakes and serpents of incredible size and different colors [...] white lions larger than bulls," enormous boars, a three-horned beast larger than an elephant called the odontotyrannus, mice as big as wolves that ate the dead, and "Bats as big as pigeons" that bit off men's noses. These animals also appear in the Abreujamen: ${ }^{39}$

E quant l'aygua fon trobada, sobreuenc gran copia de escorpios aprop una gran forsa d'unas serpens apeladas Ceraustas, gran ${ }^{40}$ re de serpens de diuersas colors, e serpens crestas e am ij. caps, e am .iij. caps, e leos blancs coma taurs, e porcs singlars sobregrans, e soyritz caluas $<$ id est rata penada $>$ grandas coma colombas, e lobas seruieas. Aprop uenc una bestia maior que elefan armada de .iij. corns. Aprop uengro ratz grans coma uolp, que ausizio los cauals. $\quad\left(\mathrm{L}^{1}\right.$, fol.14r, col. 2$)$

38 Historia de preliis, trans. Kratz, The Romances of Alexander, 48-68.

39 Historia de preliis, trans. Kratz, The Romances of Alexander, 50-51.

40 Emendation gran for guan. 
[When the water had been found, there came over a great many scorpions, along with an army of snakes called Ceraustas, many serpents of many colours, snakes with crests and with two heads, and with three heads, white bull-like lions, huge wild boars, and 'bald mice' <i.e., bats> as big as pigeons, and lynxes. Along came a beast bigger than an elephant, armed with three horns. Along came rats as big as foxes that killed the horses.]

The bats as big as pigeons cause no such problem in $\mathrm{M}$, where they are named as "uespertilicens magnitudinis columbarum." There may therefore have been a dispute over the correct vernacular word for "bat" (vespertilio in Latin). Rata penada was the correct noun in Occitan. Soritz calva is a comparatively rare Gallicism, calqued on the French chauve-souris. ${ }^{41}$ For quite different reasons, the Latinate name of the unfamiliar odontotyrannus has been discarded in favour of its description as a three-horned beast. Should the simplification of the text - along with the omission of Alexander's disputed paternity, his deification, and his illegitimate son - be viewed as censorship? It is ill advised to speculate on the basis of absence, but in this instance, it is unlikely that the translators worked with an incomplete text that limited their base material. Rather, the disagreement over an everyday noun such as "bat," the absence of some of the best-loved anecdotes of the Historia de preliis, and, above all, the gloss that explains that Bucephalus is the name of Alexander's horse indicate that there was more at stake in the Avignonese workshop than a desire to render a sense of the Latinity of the sources.

\section{Conclusion}

The Historia Alexandri is a condensed version of well-known material, but its chief interest lies in being both an incomplete rendering of the medieval tradition and a remarkably faithful translation of a classical pagan source. It presents a serious attempt to translate individual sentences and phrases closely, possibly with the unstated intention of enabling its designated reader ("vos senher") to devise his own Latin renderings of the deeds of the king. The text also reflects

41 See "Vespertiliones calves sorices" in the Reichenau glossary, in Anciens glossaires romans, ed. Diez, 9, 47, 116. 
several conscious lexical decisions on the part of its compilers and translators, who sought to erase Alexander's illegitimacy, to replace his idolatry with a narrative of conversion, and to ignore the monstrous races. Their reasons for doing so must remain obscure, but these changes draw attention to the fact that the Abreujamen was created in an ecclesiastical, mendicant milieu, one that also fostered the earliest humanist works, such as Nicholas Trevet's commentaries on Seneca's tragedies or the moralizations of Ovid by Pierre Bersuire and others. ${ }^{42}$ Indeed, the manuscript mentioned in the introduction as a plausible source for Justin's Epitome, MS Vat. Lat. 1860, combines its exceptional collection of classical histories with the Franciscan John of Wales's Breviloquium (c.1275), a series of exempla of the virtuous acts of rulers, drawn from classical sources. According to Diem and Verweij, this copy of the Breviloquium was revised in order to claim (wholly contrary to John of Wales's argument) that pagan rulers were incapable of the same kind of virtuous deeds as their Christian successors. ${ }^{43}$ Therefore, the Abreujamen's anxious treatment of pagan subjectmatter can be traced to the debates of its time concerning the moral and moralizing value of non-Christian texts.

To return to Benjamin's archaeological metaphor, the Occitan Historia Alexandri stands as a fragment of a broken vessel, that of the Alexander tradition. It is one of the minor fragments of that vast and often multifaceted corpus, but one that informs us about the way in which medieval translators approached their task, in a context where classical texts were beginning to be read in a more historicizing light. It also draws attention to the workings of ideology in a process of cultural as well as textual adaptation that is present in the Avignonese milieu of the 1320s. However, it is not a work that is easy to read, and in terms of Benjamin's definition, it is not "a real translation," in the sense that such a work should be "transparent." ${ }^{4}$ Rather, the Occitan Historia Alexandri is a thing of gaps, uncertainties, possibly as a result of censorship. Paolino's prologue to the Abreujamen (which also appears in its Latin form in $\mathrm{M}$ ) is striking for its formulation of this fragmentary, gap-filled text as evidence of an approach that stresses the value of the fragment and its relationship to the whole:

42 Botana, "Images of the Pagan Gods in L'Abreujamen de las estorias."

43 See the detailed study and editions of the relevant passages by Diem and Verweij, "Virtus est via ad gloriam."

44 Benjamin, "The Task of the Translator," 78-79. 
Enayshi com negus regardamens ne pren ni perceb la beutat del cors humanal regardada tan solamen una partida, tot en aquesta manyera no perceb ni pren lo decorremen de tot lo mon, regardada tan solamen una partida. Mas adonc la perceb quan conprehen e enten la beutat de quascunas partidas e enten la beutat de quascunas partidas en lor e l'ajustamen en lo tot e la proportio entre lor. ( $\mathrm{L}^{1}$, fol. 3r, col. 1) [Just as no gaze may grasp or perceive the beauty of the human body by looking only at one part of it, so in the same way the events in the world cannot be perceived or grasped if only one part of them is looked at. However, they are perceived when one grasps and understands the beauty of all its parts, and understands the beauty of all the parts in themselves, as well as the way that the whole is set out, and the relationship between all of them.]

In this instance, several shards of the broken vessel are reassembled, but without any effort to present a seamless artefact, in a context that was developing a greater sense of the cultural distinctiveness of the pagan classical past. The Abreujamen invites the reader to examine each of the discrete elements that make up the whole, all the better to grasp the beauty of that whole. It does not aim to be exhaustive, and it does not aim to tell the truth. Rather, its stated aim is aesthetic: it is a translation that intends to please its reader. From the perspective of a literary historian rather than a medieval reader, what makes the text innovative is the fact that its classical source material is written in the Occitan vernacular, with little use of the Old French Alexander tradition. Its very existence as a vernacular translation of Justin makes it a new and interesting work for its time.

The Abreujamen reveals the choices made by these medieval translators of various infidelities that can be termed "trans-creative." Changes were made as a function of their readership and context rather than the product of constraint. They omitted difficult sections, introduced elements of popular lore, and altered the vocabulary to make it more accessible. ${ }^{45}$ They did this, however, with an eye to a more learned reader, by paying scrupulous attention to the shape, the textual skeleton, of Justin's Epitome, which was itself an adaptation and condensation of an older work. The result is rich in significance for our knowledge of the process of vernacular translation in the later Middle Ages.

\section{University of Reading}

45 Milton, "Between the Cat and the Devil," 53, 57.

DOI: 10.3138/flor.31.03

Florilegium 31 (2014) 


\section{Bibliography}

\section{Manuscripts and Sigla}

Cambridge, Fitzwilliam Museum, MS 264

L1. London, British Library, Egerton MS 1500

L $^{2}$. London, British Library, Additional MS 17920 (originally part of L ${ }^{1}$ )

M. Venice, Biblioteca Marciana, cod. Z latino 399 (=1610)

Rome, Biblioteca apostolica vaticana, MS Vat. Lat. 1860

\section{Published Primary Sources}

Historia de preliis. In The Romances of Alexander, trans. Dennis M. Kratz, 1-82. New York: Garland, 1991.

Josephus. Jewish Antiquities. Vol. 4, Books 9-11. Trans. Ralph Marcus. Loeb Classical Library 326. Cambridge, Mass.: Harvard Univ. Press, 1937.

Justin. Abrégé des 'Histoires Philippiques' de Trogue Pompée, édition critique avec traduction française, introduction, notes et commentaire de Marie-Pierre Arnaud-Lindet. Available at <http://www.forumromanum.org/literature/justin/index.html>.

—. Epitome of the Philippic History of Pompeius Trogus. Vol. 1, Books 11-12: Alexander the Great. Trans. J. C. Yardley, with introduction and commentary by Waldemar Heckel. Oxford: Clarendon Press, 1997.

MFRA 1. La Du, Milan S., ed. Text of the Arsenal and Venice Versions. Vol. 1 of The Medieval French Roman d'Alexandre, gen. ed. Edward C. Armstrong. Princeton: Princeton Univ. Press, 1937.

MFRA 3. Foulet, Alfred, ed. Version of Alexandre de Paris: Variants and Notes to Branch I. Vol. 3 of The Medieval French Roman d'Alexandre, gen. ed. Edward C. Armstrong. Princeton: Princeton Univ. Press, 1949.

Piccat, Marco, ed. La versione occitana dello Pseudo Turpino: Ms. Londra B. M. Additional 17920. Tübingen: Niemeyer, 2001.

Ricketts, Peter. "Deux textes en occitan médiéval du ms. Londres, British Library, Add. 17920, les Miracles de Notre Dame et le Mariage des neuf filles du Diable." La Parola del testo 8, no. 2 (2004): 317-32.

_ France latine 148 (2009): 233-97.

Townsend, David, ed. An Epitome of Biblical History: Glosses on Walter of Châtillon's 'Alexandreis' 4.176-274, Edited from London, British Library, MS. Additional 18217. Toronto: Pontifical Institute of Mediaeval Studies, 2008.

Walter of Châtillon. The Alexandreis. Trans. R. Telfryn Pritchard. Toronto: Pontifical Institute of Mediaeval Studies, 1986. 


\section{Secondary Sources}

Alonso-Núñez, J. M. "An Augustan World History: The Historiae Philippicae of Pompeius Trogus." Greece and Rome, 2nd ser., 34, no. 1 (1987): 56-72.

Anciens glossaires romans. Ed. Frédéric Diez. Trans. Alfred Bauer. Paris: A. Franck, 1870. Benjamin, Walter. "The Task of the Translator." In Illuminations, edited by Hannah Arendt, trans. Harry Zohn, 69-82. New York: Harcourt, Brace \& World, 1968.

Billanovich, Giuseppe. Lezioni di filologia petrarchesca, edited by Domenico Losappio. Venice: Centro di studi E. A. Cicogna, 2008.

Bortolotti, Gary R., and Linda Hutcheon. "On the Origin of Adaptations: Rethinking Fidelity Discourse and 'Success' - Biologically." New Literary History 38, no. 3 Biocultures (2007): 443-58.

Bossuat, Robert. "Vasque de Lucene, traducteur de Quinte-Curce (1468)." Bibliothèque d'Humanisme et Renaissance 8 (1946): 197-245.

Botana, Federico. "Images of the Pagan Gods in L'Abreujamen de las estorias: Histories and Allegories." Paper given at the Leeds International Medieval Congress, 9-12 July 2012.

_- "The Making of L'Abreujamen de las estorias (Egerton MS. 1500)." eBLJ (Electronic British Library Journal) (2013), art. 16. Available at <http://www.bl.uk/eblj/>.

Campopiano, Michele. "Parcours de la légende d'Alexandre en Italie. Réflexions sur la réception italienne de l'Historia de Preliis, recensio J2 (XII ${ }^{e}-\mathrm{XV}^{e}$ siècles)." In L'historiographie médiévale d'Alexandre le Grand, edited by Catherine GaullierBougassas, 65-83. Turnhout: Brepols, 2011.

Cary, George. The Medieval Alexander, ed. D. J. A. Ross. Cambridge: Cambridge Univ. Press, 1956.

Cohen, Shaye J. D. "Alexander the Great and Jaddus the High Priest According to Josephus." AJS Review 7-8 (1982-83): 41-68.

Degenhart, Bernhard, and Annegrit Schmitt. "Marino Sanudo und Paolino Veneto:

Zwei Literaten des 14. Jahrhunderts in ihrer Wirkung auf Buchillustrierung und Kartographie in Venedig, Avignon und Neapel." Römisches Jahrbuch für Kunstgeschichte 14 (1973): 1-137.

Diem, Albrecht, and Michiel Verweij. "Virtus est via ad gloriam? John of Wales and Michele da Massa in Disagreement." Franciscan Studies 63 (2005): 215-69.

Gaullier-Bougassas, C. Les Romans d'Alexandre: Aux frontières de l'épique et du romanesque. Paris: Champion, 1998.

Ghinato, Alberto. Fr. Paolino da Venezia, O.F.M.: Vescovo di Pozzuoli. Rome: Edizione Francescane, 1951. 
Gilbert, Jane. "The Task of the Dérimeur: Benjamin and Translation into Prose in Fifteenth-Century French Literature." In Rethinking Medieval Translation: Ethics, Politics, Theory, edited by Emma Campbell and Robert Mills, 164-83. Cambridge: D. S. Brewer, 2012.

Gosman, Martin. La légende d'Alexandre le Grand dans la littérature française du $12^{e}$ siècle: Une réécriture permanente. Amsterdam: Rodopi, 1997.

—. "The Life of Alexander the Great in Jean de Vignay's Miroir Historial: The Problem of Textual Equivalence." In Vincent of Beauvais and Alexander the Great: Studies on the 'Speculum Maius' and its Translations into Medieval Vernaculars, edited by W. J. Aerts, E. R. Smits, and J. B. Voorbij, 85-99. Groningen: Egbert Forsten, 1986.

Griffin, Miranda. "Translation and Transformation in the Ovide moralisé." In Rethinking Medieval Translation: Ethics, Politics, Theory, edited by Emma Campbell and Robert Mills, 41-60. Cambridge: D. S. Brewer, 2012.

Heullant-Donat, Isabelle. "Ab Origine Mundi. Fra Elemosina e Paolino da Venezia. Deux Franciscains italiens et l'histoire universelle au XIVe siècle." PhD diss., 3 vols., Paris, 1994.

—. "Entrer dans l'histoire. Paolino da Venezia et les prologues de ses chroniques universelles." Mélanges de l'Ecole Française de Rome: Moyen Âge 105, no. 1 (1993): 381-442.

Ibarz, Alexander. "The Provenance of the Abreujamens de las estorias (London, British Library, Egerton MS. 1500) and the Identification of Scribal Hands (c.1323)." eBLJ (2013), art. 17. Available at <http://www.bl.uk/eblj/>.

Kelly, Douglas. "The Fidus interpres: Aid or Impediment to Medieval Translation and Translatio?" In Translation Theory and Practice in the Middle Ages, edited by Jeanette Beer, 47-58. Kalamazoo, Mich.: Western Michigan Univ., Medieval Institute Publications, 1997.

Léglu, Catherine. "The Child of Babylon and the Problem of Paternity in Medieval French Alexander Romances." Reading Medieval Studies 39 (2013): 81-96.

- "The Devil's Daughters and a Question of Translation between Occitan and Anglo-Norman French: 'De las .vii. filhas del diable' (British Library Add. MS 17920)." La France latine 160 (2015): 93-123.

- "A Genealogy of the Kings of England in Papal Avignon: British Library, Egerton MS. 1500." eBLJ (2013), art. 18. Available at <http://www.bl.uk/eblj/>.

—. "Translating Lucretia: Word, Image and 'Ethical Non-Indifference' in Simon de Hesdin's Translation of Valerius Maximus's Facta et dicta memorabilia." In Rethinking Medieval Translation: Ethics, Politics, Theory, edited by Emma Campbell and Robert Mills, 61-83. Cambridge: D. S. Brewer, 2012.

Long, Lynne. "Medieval Literature through the Lens of Translation Theory: Bridging the Interpretive Gap." Translation Studies 3, no. 1 (2010): 61-77. 
Lusignan, Serge. Parler vulgairement: Les intellectuels et la langue française aux XIII et XIVe siècles. Paris: Vrin; Montréal: Les Presses de l'Université de Montréal, 1986.

Milton, John. "Between the Cat and the Devil: Adaptation Studies and Translation Studies." Journal of Adaptation in Film E Performance 2, no. 1 (2009): 47-64.

Morosini, Roberta. "Boccaccio 'secundum venetum': il De regno saracenorum di Paolino Veneto nello Zibaldone magliabechiano. Con una nota sull'arcangelo Michele nel Mare historiarum di G. Colonna." Le tre corone 3 (2016): 93-124.

Reynolds, L. D. "Justinus." In Texts and Transmission: A Survey of the Latin Classics, ed. L. D. Reynolds, 197-99. Oxford: Clarendon Press, 1983.

Ross, D. J. A. Alexander Historiatus: A Guide to Medieval Illustrated Alexander Literature. Frankfurt am Main: Athenäum, 1987.

—. Illustrated Medieval Alexander Books in Germany and the Netherlands: A Study in Comparative Iconography. Cambridge: Modern Humanities Research Association, 1971.

Syme, Ronald. "The Date of Justin and the Discovery of Trogus." Historia: Zeitschrift für Alte Geschichte 37, no. 3 (1988): 358-71.

Voorbij, J. B. "The Speculum Historiale: Some Aspects of its Genesis and Manuscript Tradition." In Vincent of Beauvais and Alexander the Great: Studies on the 'Speculum Maius' and its Translations into Medieval Vernaculars, edited by W. J. Aerts, E. R. Smits, and J. B. Voorbij, 11-55. Groningen: Egbert Forsten, 1986. 